\title{
GAYA KEPEMIMPINAN TRANSFORMASIONAL BERPENGARUH TERHADAP ORGANIZATIONAL CITIZENSHIP BEHAVIOUR DENGAN DIMEDIASI VARIABEL KEPUASAN KERJA
}

\author{
I Nyoman Adi Wisnawa ${ }^{1}$ \\ A.A Sagung Kartika Dewi ${ }^{1}$ \\ ${ }^{1,2}$ Fakultas Ekonomi dan Bisnis Universitas Udayana (Unud), Bali, Indonesia \\ email: adiwisnawa97@gmail.com
}

\begin{abstract}
ABSTRAK
Tujuan penelitian ini adalah untuk mengetahui pengaruh gaya kepemimpinan transformasional terhadap Organizational Citizenship Behaviour (OCB), untuk mengetahui pengaruh gaya kepemimpinan transformasional terhadap kepuasan kerja, untuk mengetahui pengaruh kepuasan kerja terhadap Organizational Citizenship Behavior (OCB), serta untuk mengetahui peran kepuasan kerja dalam memediasi pengaruh gaya kepemimpinan transformasional terhadap Organizational Citizenship Behavior (OCB). Penelitian ini dilakukan di Kantor Desa Ubung Kaja sebanyak 45 pegawai dengan menggunakan metode sampel jenuh, dikumpulkan melalui kuesioner menggunakan teknik analisis statistik deskriptif, analisis jalur, uji sobel dan uji VAF. Hasil penelitian menunjukkan bahwa gaya kepemimpinan transformasional berpengaruh positif dan signifikan terhadap Organizational Citizenship Behaviour (OCB). Gaya kepemimpinan transformasional berpengaruh positif dan signifikan terhadap kepuasan kerja. Kepuasan kerja berpengaruh positif dan signifikan terhadap Organizational Citizenship Behaviour (OCB). Kepuasan kerja secara positif dan signifikan memediasi pengaruh gaya kepemimpinan transformasional terhadap Organizational Citizenship Behaviour (OCB).

Kata kunci: Gaya Kepemimpinan Transformasional; Kepuasan Kerja; Organizational Citizenship Behaviour.
\end{abstract}

\begin{abstract}
The purpose of this study was to determine the effect of transformational leadership style on Organizational Citizenship Behavior (OCB), to determine the effect of transformational leadership style on job satisfaction, to determine the effect of job satisfaction on Organizational Citizenship Behavior (OCB), and to determine the role of job satisfaction in mediating the influence of job satisfaction transformational leadership style towards Organizational Citizenship Behavior (OCB). This research was conducted at the Office of the Ubung Kaja Village as many as 45 employees using the saturated sample method, collected through a questionnaire using descriptive statistical analysis techniques, path analysis, single test and VAF test. The results showed that the transformational leadership style had a positive and significant effect on Organizational Citizenship Behavior (OCB). Transformational leadership style has a positive and significant effect on job satisfaction. Job satisfaction has a positive and significant effect on Organizational Citizenship Behavior (OCB). Job satisfaction positively and significantly mediates the effect of transformational leadership styles on Organizational Citizenship Behavior (OCB).

Keywords: Transformational Leadership Style; Job satisfaction; Organizational Citizenship Behavior.
\end{abstract}




\section{PENDAHULUAN}

Sumber daya manusia tidak cukup hanya melakukan tugasnya masingmasing sesuai dengan job description saja namun harus juga memiliki perilaku ekstra peran atau OCB dalam bekerja di suatu perusahaan atau perkantoran yang dapat memberi pengaruh positif bagi organisasi. Sebuah organisasi akan mencapai keberhasilan apabila memiliki sumber daya manusia yang bersedia melakukan pekerjaan di luar tugas pokok. Dengan kata lain sumber daya manusia tersebut memiliki inisiatif untuk melakukan peran-ekstra di luar tugas pokoknya dalam upaya pencapaian tujuan organisasi. Organisasi yang sukses membutuhkan sumber daya manusia yang akan melakukan sesuatu lebih dari sekedar tugas pokok mereka dan bersedia memberikan kinerja yang melebihi harapan.

Perilaku yang tidak termasuk dalam kontrak kerja atau uraian pekerjaan, dan bermanfaat untuk organisasi adalah OCB (Cichorzewska \& Rakowska, 2017). Pegawai melakukannya tanpa harapan penghargaan, termotivasi oleh keinginan intrinsik untuk mendukung organisasi dan perkembangannya (Nezakati et al., 2010). Oleh karena itu, gaya kepemimpinan dan kepuasan kerja pegawai Kantor Desa Ubung Kaja memainkan peran penting untuk meningkatkan OCB pada organisasi tersebut. Pada kondisi sebenarnya di Kantor Desa Ubung Kaja menurut pengamatan penelitian, masih kurangnya perilaku OCB yang ditunjukkan dari pegawainya. Permasalahan yang terjadi di Kantor Desa Ubung Kaja adalah pegawai cenderung hanya berkutat untuk menyelesaikan tugasnya sendiri, kurangnya kepedulian pegawai terhadap rekan kerjanya di saat rekan kerjanya mendapatkan beban kerja yang lebih, tidak terbuka terhadap pengalaman atau informasi baru, kurang komunikatif dengan rekan kerja, dan kurang ada kerjasama yang baik antar rekan kerja. Selain itu kurangnya dedikasi yang tinggi pada pekerjaan ditunjukkan oleh pegawai Kantor Desa Ubung Kaja terlihat dari banyaknya pegawai yang datang terlambat dan meninggalkan kantor sebelum jam kerja berakhir. Kenyataan tersebut mengindikasikan bahwa pegawai di Kantor Desa Ubung Kaja selama ini masih berkutat untuk mampu berusaha mengerjakan tugas-tugas pokok mereka (intra-role) dan belum sedikit pun menyentuh kepada tugas-tugas di luar tanggung jawabnya (extra-role). Padahal dalam berbagai penelitian, perilaku extra-role atau sering disebut sebagai $\mathrm{OCB}$, sangat penting dalam mendukung kemajuan organisasi. OCB merupakan perilaku yang melampaui panggilan tugas dan dilakukan secara sukarela.

Pemimpin mengkomunikasikan visi, misi, dan tujuan organisasi secara jelas, sehingga meningkatkan kreativitas dan inovasi bawahan. Gaya kepemimpinan transformasional merupakan proses mempengaruhi individu untuk mencapai tujuan organisasi dengan mendahulukan kepentingan organisasi dan mengesampingkan kepentingan pribadi (Kreitner \& Kinicki, 2014).

Para pemimpin yang memiliki gaya kepemimpinan transformasional mendorong kewajiban pengikut untuk mencapai misi dan nilai-nilai perusahaan serta memotivasi mereka dengan membangun kepercayaan dan tujuan bersama (Guay \& Choi, 2015). Menurut (Trmal et al., 2015) menyatakan bahwa kepemimpinan transformasional sangat efektif karena mendorong perubahan dalam perilaku individu yang mengarah pada pencapaian tujuan organisasi, akibatnya gaya kepemimpinan transformasional memiliki potensi untuk memiliki 
dampak yang substansial pada kinerja keseluruhan organisasi dan menciptakan dukungan yang diperlukan untuk memastikan hasil yang diinginkan.

Gaya kepemimpinan transformasional berpengaruh terhadap kepuasan kerja yang dirasakan bawahannya (Bushra et al., 2011). Gaya kepemimpinan transformasional berfokus pada memuaskan kebutuhan dasar dan kebutuhan dengan tingkatan yang lebih tinggi dari pengikut melalui inspirasi untuk mencapai tujuan yang diinginkan (Ghasabeh et al., 2015). Perhatian dan hubungan yang baik dari pimpinan kepada bawahan, dapat meningkatkan kepuasan kerja karyawan sehingga karyawan akan merasakan dirinya merupakan bagian yang penting dari organisasi kerja (Retnaningsih, 2007).

Dalam kondisi kerja yang dirasakan pegawai Kantor Desa Ubung Kaja merasa kurang puas dengan rekan kerjanya, dimana masih sering terjadi komunikasi yang kurang baik saat bekerja dan diperlukannya rekan kerja yang saling mendukung dan membantu dalam lingkungan kerja sehingga hal ini menyebabkan OCB di Kantor Desa Ubung Kaja masih rendah. Menurut Permatasari (2016) kepuasan kerja memotivasi pegawai untuk melakukan OCB secara sukarela, sehingga dapat dikatakan bahwa kepuasan kerja menjadi faktor penting dari OCB (Zadeh et al., 2015). OCB dapat timbul dari berbagai faktor dalam organisasi, di antaranya karena adanya kepuasan kerja dari pegawai (Robins \& Judge, 2012).

Definisi kepemimpinan bervariasi dari orang ke orang. Kepemimpinan memainkan peran penting dalam membina dan meningkatkan perilaku karyawan di organisasi (Khalili, 2016). Kepemimpinan dijelaskan sebagai kemampuan untuk mempengaruhi pengikut untuk mendapatkan tugas yang dilakukan di tempat kerja. Gaya kepemimpinan transformasional berkontribusi terhadap kesejahteraan organisasi dan individu yang membentuk organisasi (misalnya produktivitas organisasi serta kesehatan mental karyawan (Chun et al., 2016).

Perilaku pegawai yang melebihi persyaratan peran kerja disebut dengan OCB (Kreitner \& Kinicki, 2014), sedangkan Griffin (2008) mengemukakan definisi OCB dengan merujuk pada perilaku invidu yang memberikan kontribusi positif kepada organisasi. Robins \& Judge (2012) menegaskan bahwa karyawan dengan tingkat OCB yang tinggi cenderung sering membantu orang lain dalam timnya, sukarela mengerjakan pekerjaan tambahan, bertoleransi atas pembebanan dan gangguan pekerjaan sewaktu-waktu, sedangkan yang kurang terlibat dalam OCB cenderung tidak tepat waktu dalam bekerja dan tidak dapat mentoleransi keadaaan yang kurang ideal yang menyebabkan tingginya tingkat perputaran. Hal ini sesuai dengan penelitian yang dilakukan oleh Astrayana \& Sriathi (2014), Rahman et al. (2014) dan Dewi \& Subudi (2015). Semakin tinggi nilai Gaya Kepemmpinan Transformasional yang ditunjukkan pemimpin maka kepuasan kerja dari pegawai akan meningkat. Berdasarkan hasil penelitian tersebut dapat dikemukakan hipotesis sebagai berikut:

$\mathrm{H}_{1}$ : Gaya kepemimpinan transformasional berpengaruh positif terhadap

Kepuasan Kerja.

Sesuai dengan penelitian Jha (2014), Abu \& Heilbrunn (2016), Kartikaningdyah \& Utami (2017), Rahmi (2014), Iswara \& Sriathi (2016) yang menyatakan bahwa kepemimpinan transformasional mempunyai pengaruh yang 
positif dan signifikan terhadap OCB. Tingginya nilai kepemimpinan transformasional dapat berpengaruh terhadap organizational citizenship behavior (OCB) pegawai.

Penelitian dari Permatasari et al., (2017) terhadap 32 karyawan pada PT Bank Panin cabang Banjarbaru juga menunjukkan adanya pengaruh signifikan antara kepemimpinan transformasional dan OCB. Semakin tinggi tingkat kepemimpinan transformasional oleh pemimpin, maka tingkat organizational citizenship behavior (OCB) pegawai juga akan semakin meningkat. Berdasarkan hasil penelitian tersebut dapat dikemukakan hipotesis sebagai berikut :

$\mathrm{H}_{2}$ : Gaya kepemimpinan berpengaruh positif terhadap Organizational

Citizenship Behaviour.

Penelitian menyatakan kepuasan kerja berpengaruh positif dan signifikan terhadap perilaku Organizational Citizenship Behavior Mushtaq \& Umar (2015), Rahman et al. (2014), Dewanggana et al. (2016), Subawa \& Suwandana (2017). Penelitian terdahulu yang dilakukan oleh Dewi \& Suwandana (2016) terhadap 41 karyawan hotel juga menunjukkan bahwa kepuasan kerja karyawan berpengaruh secara positif dan signifikan terhadap OCB. Semakin tinggi kepuasan kerja, maka organizational citizenship behavior akan semakin meningkat. Berdasarkan pernyataan di atas maka dapat dirumuskan hipotesis sebagai berikut :

$\mathrm{H}_{3}$ : Kepuasan Kerja berpengaruh positif terhadap Organizational

Citizenship Behaviour.

Penelitian sebelumnya yang dilakuka oleh Bushra et al., (2011) menyatakan kepemimpinan transformasional berpengaruh terhadap kepuasan kerja karena gaya kepemimpinan transformasional akan membuat karyawan bekerja dengan puas dan kepuasan kerja merupakan determinan penting yang mendorong seseorang memperlihatkan perilaku Organizational Citizenship Behavior (OCB), disebabkan karena individu-individu yang mendapatkan kepuasan dalam pekerjaannya, akan cenderung memaknai pekerjaan dan tugas-tugas yang ia laksanakan dengan penuh tanggung-jawab dan dedikasi Ristiana (2013). Hal ini juga didukung dari penelitian Kartono et al. (2015), Purwaningsih \& Liana (2015), Arifiani et al. (2016) bahwa kepuasan kerja memediasi pengaruh gaya kepemimpinan transformasional terhadap OCB. Berdasarkan hasil penelitian tersebut dapat dikemukakan hipotesis sebagai berikut

$\mathrm{H}_{4}$ : Kepuasan Kerja menjadi mediasi pada hubungan Gaya Kepemimpinan

Trasformasional terhadap Organizational Citizenship Behaviour.

\section{METODE PENELITIAN}

Jenis penelitian ini menggunakan desain penelitian asosiatif dimana penelitian asosiatif adalah penelitian yang bertujuan untuk mengetahui pengaruh antara dua variabel atau lebih. Penelitian ini menguji pengaruh Gaya Kepemimpinan Transformasional terhadap Organizational Citizenship Behaviour (OCB) dengan Kepuasan Kerja sebagai variabel pemediasi. Lokasi penelitian ini dilakukan di Kantor Desa Ubung Kaja, Jl. Ken Dedes, Denpasar, Bali. Lokasi ini dipilih karena ditemukan masalah-masalah yang terkait dengan Gaya Kepemimpinan Transformasional, Kepuasan Kerja dan Organizational 
Citizenship Behaviour (OCB). Selain itu, pemilihan lokasi ini didasarkan atas tersedianya data yang memadai dan mampu untuk diolah peneliti.

Obyek dari penelitian ini adalah Gaya Kepemimpinan Transformasional, Kepuasan Kerja dan Organizational Citizenship Behaviour (OCB). Identifikasi variabel dalam penelitian ini adalah sebagai berikut, 1) Independent variable (variabel bebas) adalah variabel yang mempengaruhi atau menjadi sebab perubahannya atau timbulnya variabel terikat (Sugiyono, 2017). Variabel bebas dalam penelitian ini adalah Gaya Kepemimpinan Transformasional, 2) Dependent variable (variabel terikat) adalah variabel yang dipengaruhi atau yang menjadi akibat karena adanya variabel bebas (Sugiyono, 2017). Variabel terikat dalam penelitian ini adalah OCB, 3) Variabel pemediasi adalah variabel antara yang menghubungkan sebuah variabel bebas utama pada variabel terikat yang dianalisis. Variabel mediasi disini berfungsi sebagai dependent atau endogen variabel, dimana terdapat anak panah yang menuju variabel ini berfungsi untuk menjelaskan jumlah varians yang tidak dapat dijelaskan oleh variabel itu (Sugiyono, 2017). Variabel pemediasi dalam penelitian ini adalah Kepuasan Kerja.

Definisi operasional variabel penelitian ini adalah sebagai berikut, Gaya Kepemimpinan Transformasional adalah gaya kepemimpinan yang dapat mempengaruhi bawahan untuk menunjukkan perilaku ektra (OCB) dan membuat bawahannya merasakan kepuasan saat menjalankan pekerjaannya. Adapun indikator yang digunakan untuk mengukur Gaya Kepemimpinan Transformasional mengacu pada Long (2014) di Kantor Desa Ubung Kaja yaitu 1) Inspirational Motivation diukur dari persepsi responden mengenai pemimpin memberikan motivasi dalam bekerja, menumbuhkan rasa percaya diri saat bekerja, memberikan keyakinan bahwa tujuan akan tercapai, membangkitkan rasa antusiasme, dan melakukan komunikasi dengan jelas, 2) Idealized Infuence diukur dari persepsi responden mengenai pemimpin merupakan role model dalam perusahaan, memberikan petunjuk bagaimana menyelesaikan pekerjaan, menanamkan rasa bangga dengan perusahaan dan mendapatkan rasa hormat dari pegawai, 3)Intelectual Stimulation diukur dari persepsi responden mengenai kemampuan pemimpin untuk mendorong kreativitas, inovasi, mendengarkan ide atau gagasan bawahannya, menyelesaikan masalah secara rasional/logis, dan menyelesaikan masalah dari berbagai sudut pandang, 3) Individual Consideration diukur dari persepsi responden mengenai pemimpin meningkatkan pengembangan diri bawahannya, memperlakukan bawahan sebagai individu pribadi bukan hanya sebagai anggota kelompok kerja, bersedia mendengarkan kesulitan atau keluhan bawahannya, memberikan nasihat untuk pengembangan diri, memperlakukan pegawai sebagi individu yang memiliki kebutuhan, kemampuan dan aspirasi yang berbeda.

Kepuasan Kerja adalah mencerminkan sikap dan perasaan seseorang pegawai terhadap pekerjaannya, rekan kerja atau pemimpinnya dan segala sesuatu yang dihadapi di lingkungan kerjanya. Adapun indikator yang digunakan untuk mengukur kepuasan kerja mengacu pada Azeem (2010) di Kantor Desa Ubung Kaja yaitu 1) Gaji (Pay) diukur dari persepsi responden mengenai gaji yang diterima sesuai dengan pekerjaan yang dilakukan dan bersedia bekerja lebih keras 
karena gaji, 2) Pekerjaan ( $J o b)$ diukur dari persepsi responden mengenai pekerjaan yang dilakukan menarik dari waktu ke waktu, memiliki kesempatan untuk mengerjakan pekerjaan dengan cara sendiri dan memadai untuk melakukan pekerjaan saat ini, 3) Kesempatan Promosi (Promotion Opportunities) diukur dari persepsi responden mengenai kesempatan untuk menjadi seseorang yang diperhitungkan dalam organisasi, memberi peluang untuk belajar keterampilan baru dan adanya kebebasan untuk menggunakan penilaian sendiri, 4) Rekan kerja (Co-warkers) diukur dari persepsi responden mengenai kesempatan untuk melakukan banyak hal bagi pegawai lain dan hubungan dengan rekan kerja, 5) Atasan (Supervisor) diukur dari persepsi responden mengenai cara pemimpin menangani bawahannya dan pemimpin memiliki kemampuan untuk membuat keputusan dengan cepat dan tepat.

Organizational Citizenship Behaviour (OCB). OCB merupakan kepedulian pegawai terhadap rekan kerjanya dan secara sekarela tanpa mengharapkan imbalan untuk melakukan tugas diluar deskripsi pekerjaanya. Adapun indikator yang digunakan untuk mengukur OCB mengacu pada Ahmed et al. (2012); Chiang \& Hsieh (2012) di Kantor Desa Ubung Kaja yaitu 1) Altruism diukur dari persepsi responden yang memberikan bantuan kepada rekan kerja tanpa mengharapkan imbalan, menggantikan rekan kerja yang tidak masuk/istirahat, dan bekerja lembur membantu rekan kerja menyelesaikan pekerjaannya tanpa dikenakan gaji lembur, 2) Conscientiousness diukur dari persepsi responden yang merasa puas jika pekerjaannya selesai tepat pada waktunya, menyelesaikan pekerjaan dengan tanggung jawab, dan berani mengambil resiko untuk bertanggung jawab melaksanakan hasil keputusan rapat bersama, 3) Courtesy diukur dari persepsi responden yang selalu terlibat dalam fungsi-fungsi perusahaan, pernah mengajak rekan kerja makan siang dan sharing mengenai masalah yang dihadapi dan pernah mengingatkan teman agar tidak lupa menyelesaikan pekerjaannya, 4) Sportmanship diukur dari persepsi responden yang mudah beradaptasi dengan perubahan yang terjadi dalam perusahaan, tidak pernah mengeluh tentang tugas dan kebijakan perusahaan, menyesuaikan diri dengan kebijakan baru dari perusahaan, 5) Civic Virtue diukur dari persepsi responden yang rutin mengikuti kegiatan yang diadakan perusahaan, tertarik mencari informasi penting yang bermanfaat untuk perusahaan dan selalu mempertimbangkan hal-hal terbaik untuk kemajuan perusahaan.

Populasi dalam penelitian ini adalah seluruh pegawai Kantor Desa Ubung Kaja yang berjumlah 45 orang. Sugiyono (2017) menjelaskan sampel jenuh adalah teknik penentuan sampel apabila semua anggota populasi digunakan sebagai sampel, hal ini sering dilakukan bila jumlah populasi relatif kecil,berkisar dibawah 100 orang sehingga jumlah sampel yang diambil adalah sebanyak 45 orang dengan menggunakan teknik penentuan sampel jenuh.

Metode pengumpulan data dilakukan dengan cara sebagai berikut. Wawancara, Teknik wawancara digunakan sebagai teknik pengumpulan data dengan wawancara langsung untuk memperoleh informasi mengenai penilaian responden mengenai bagaimana pengaruh Gaya Kepemimpinan Transformasional terhadap OCB dengan Kepuasan Kerja sebagai variabel mediasi di Kantor Desa Ubung Kaja. Kuisioner, Sugiyono (2017) mendefinisikan kuisioner sebagai teknik 
pengumpulan data yang dilakukan dengan cara memberi seperangkat pertanyaan atau pernyataan tertulis kepada responden untuk dijawabnya.

Jenis data yang digunakan dalam penelitian ini adalah sebagai berikut. Data Kuantitatif adalah data yang dapat dinyatakan dalam bentuk angka-angka dan dapat dihitung dengan satuan hitung. Sehingga data kuantitatif dalam penelitian ini adalah jumlah pegawai serta jumlah skor jawaban kuisioner yang terdiri atas data Gaya Kepemimpinan Transformasional, Kepuasan Kerja, dan Organizational Citizenship Behaviour (OCB). Data Kualitatif adalah data yang tidak berbentuk angka-angka, hanya berupa penjelasan-penjelasan dan tidak dapat diukur dengan satuan hitung. Data kualitatif yang dimaksud dalam penelitian ini adalah gambaran umum dari perusahaan yang diteliti. Sumber data yang digunakan dalam penelitian ini adalah sebagai berikut. Sumber primer yang digunakan adalah data yang didapatkan melalui pemberian kuisioner kepada responden yaitu pegawai Di Kantor Desa Ubung Kaja. Sumber sekunder yang digunakan adalah data perusahaan berupa laporan yang telah dibuat oleh perusahaan seperti gambaran umum dari Kantor Desa Ubung Kaja.

\section{HASIL DAN PEMBAHASAN.}

Berdasarkan hasil analisis karakteristik responden berdasarkan umur, diperoleh hasil yang dijabarkan sebagai berikut.

Tabel 1.

Karakteristik Responden Menurut Umur (Tahun) Pada Kantor Desa Ubung Kaja

\begin{tabular}{llcl}
\hline No & Umur (Tahun) & Jumlah (Orang) & $\begin{array}{l}\text { Jumlah } \\
\text { (Persentase \%) }\end{array}$ \\
\hline 1 & $26-30$ Tahun & 5 & 11,1 \\
2 & $31-35$ Tahun & 7 & 15,6 \\
3 & 36 - 40 Tahun & 8 & 17,8 \\
4 & $>$ 40 Tahun & 25 & 55,6 \\
& Jumlah & 45 & 100 \\
\hline
\end{tabular}

Sumber: Data diolah, 2019

Tabel 1. menunjukkan bahwa responden dengan usia lebih dari 40 tahun yang paling mendominasi diantara usia lainnya yakni 25 orang atau 55,6\%. Sedangkan responden dengan usia 26-30 tahun yang paling sedikit yakni 5 orang atau $11,1 \%$. Hal ini dikarenakan responden berumur diatas 40 tahun lebih bertanggung jawab dalam bekerja dan sangat mengerti dengan pekerjaannya.

Berdasarkan hasil analisis karakteristik responden berdasarkan jenis kelamin, diperoleh hasil yang dijabarkan sebagai berikut.

Tabel 2. menunjukkan bahwa responden dengan jenis kelamin laki - laki lebih mendominasi yakni 34 orang atau $75,6 \%$. Sedangkan responden dengan jenis kelamin perempuan sebanyak 11 orang atau $24,4 \%$.

Pada Tabel 2. menunjukkan bahwa jenis kelamin laki-laki lebih berminat untuk bekerja di kantor desa Ubung Kaja dibandingkan jenis kelamin perempuan dan mendapatkan kepercayaan dari masyarakat desa seperti contohnya jabatan kepala dusun dan perbekel Desa Ubung Kaja dijabat oleh jenis kelamin laki-laki 
dimana jabatan perbekel dan kepala dusun dipilih berdasarkan suara dari masyarakat Desa Ubung Kaja tersebut.

Tabel 2.

Karakteristik Responden Menurut Jenis Kelamin Pada Kantor Desa Ubung Kaja

\begin{tabular}{|c|c|c|c|}
\hline No & Jenis Kelamin & Jumlah (Orang) & $\begin{array}{l}\text { Jumlah (Persentase } \\
\%)\end{array}$ \\
\hline 1 & Laki - Laki & 34 & 75,6 \\
\hline \multirow[t]{2}{*}{2} & Perempuan & 11 & 24,4 \\
\hline & Jumlah & 45 & 100 \\
\hline
\end{tabular}

Sumber: Data diolah, 2019

Tabel 3.

Karakteristik Responden Menurut Pendidikan Formal Terakhir Pada Kantor Desa Ubung Kaja

\begin{tabular}{llcc}
\hline No & Pendidikan Formal Terakhir & Jumlah (Orang) & $\begin{array}{l}\text { Jumlah } \\
\text { (Persentase \%) }\end{array}$ \\
\hline 1 & SLTA & 22 & 48,9 \\
2 & Diploma & 2 & 4,4 \\
3 & Sedang Menempuh S1 & 4 & 8,9 \\
4 & Lulus S1 & 15 & 33,3 \\
5 & Lulus S2 & 2 & 4,4 \\
& Jumlah & 45 & 100 \\
\hline
\end{tabular}

Sumber: Data diolah, 2019

Tabel 3. menunjukkan bahwa responden dengan pendidikan formal terakhir SLTA yang paling mendominasi diantara pendidikan formal lainnya yakni 22 orang atau 48,9\%. Sedangkan responden yang paling sedikit adalah responden dengan pendidikan formal terakhir lulus S2 yakni 2 orang atau 4,4\%. Hal ini dikarenakan pegawai dengan tingkat pendidikan formal terakhir SLTA lebih loyal dan lebih berminat untuk bekerja di Kantor Desa Ubung Kaja daripada pegawai dengan pendidikan formal terakhir S1 atau S2 yang lebih memilih untuk bekerja diluar Kantor Desa Ubung Kaja.

Tabel 4. menunjukkan bahwa responden dengan lama masa kerja lebih dari 5 tahun yang paling mendominasi diantara lama masa kerja yang lainnya yakni 23 orang atau $51,1 \%$. Sedangkan responden yang paling sedikit adalah responden dengan lama masa kerja 2 - 3 tahun dan lama masa kerja 4 - 5 tahun yakni masing - masing 5 orang atau $11,1 \%$.

Tabel 4.

Karakteristik Responden Menurut Lama Masa Kerja Pada Kantor Desa Ubung Kaja

\begin{tabular}{llll}
\hline No & Lama Masa Kerja & Jumlah (Orang) & $\begin{array}{l}\text { Jumlah } \\
\text { (Persentase \%) }\end{array}$ \\
\hline 1 & 1 - 2 Tahun & 12 & 26,7 \\
2 & $2-3$ Tahun & 5 & 11,1 \\
3 & 4 - 5 Tahun & 5 & 11,1 \\
4 & > 5 Tahun & 23 & 51,1 \\
& Jumlah & 45 & 100 \\
\hline
\end{tabular}

Sumber: Data diolah, 2019 
Hasil uji validitas pada Tabel 5. menunjukkan bahwa seluruh instrumen penelitian yang digunakan untuk mengukur variabel gaya kepemimpinan transformasional, kepuasan kerja dan organizational citizenship behavior memiliki nilai koefisien korelasi dengan skor total seluruh item pernyataan lebih besar dari 0,3. Hal ini menunjukkan bahwa butir-butir pernyataan dalam instrument penelitian tersebut valid dan layak digunakan sebagai instrument penelitian.

Tabel 5.

Rekapitulasi Hasil Uji Validitas Instrumen Penelitian

\begin{tabular}{|c|c|c|c|c|}
\hline Variabel & Indikator & $\begin{array}{l}\text { Koefisien } \\
\text { Korelasi }\end{array}$ & $\begin{array}{l}\text { Koefisien } \\
\text { Batas }\end{array}$ & Keterangan \\
\hline \multirow{19}{*}{$\begin{array}{l}\text { Gaya Kepemimpinan } \\
\text { Transformasional (X) }\end{array}$} & $X_{.1}$ & 0,578 & 0,3 & Valid \\
\hline & $\mathrm{X}_{.2}$ & 0,739 & 0,3 & Valid \\
\hline & $\mathrm{X}_{.3}$ & 0,699 & 0,3 & Valid \\
\hline & $\mathrm{X}_{4}$ & 0,516 & 0,3 & Valid \\
\hline & $\mathrm{X}_{.5}$ & 0,608 & 0,3 & Valid \\
\hline & $\mathrm{X}_{.6}$ & 0,688 & 0,3 & Valid \\
\hline & $\mathrm{X}_{.7}$ & 0,596 & 0,3 & Valid \\
\hline & $\mathrm{X}_{.8}$ & 0,612 & 0,3 & Valid \\
\hline & $\mathrm{X}_{9}$ & 0,587 & 0,3 & Valid \\
\hline & $\mathrm{X}_{.10}$ & 0,559 & 0,3 & Valid \\
\hline & $\mathrm{X}_{.11}$ & 0,648 & 0,3 & Valid \\
\hline & $\mathrm{X}_{.12}$ & 0,713 & 0,3 & Valid \\
\hline & $X_{.13}$ & 0,559 & 0,3 & Valid \\
\hline & $\mathrm{X}_{.14}$ & 0,627 & 0,3 & Valid \\
\hline & $X_{.15}$ & 0,572 & 0,3 & Valid \\
\hline & $\mathrm{X}_{.16}$ & 0,528 & 0,3 & Valid \\
\hline & $X_{.17}$ & 0,657 & 0,3 & Valid \\
\hline & $\mathrm{X}_{.18}$ & 0,619 & 0,3 & Valid \\
\hline & $X_{.19}$ & 0,518 & 0,3 & Valid \\
\hline \multirow{11}{*}{ Kepuasan Kerja (M) } & $M_{.1}$ & 0,720 & 0,3 & Valid \\
\hline & $\mathrm{M}_{22}$ & 0,701 & 0,3 & Valid \\
\hline & $\mathrm{M}_{3}$ & 0,736 & 0,3 & Valid \\
\hline & M.4 & 0,833 & 0,3 & Valid \\
\hline & M.5 & 0,731 & 0,3 & Valid \\
\hline & M.6 & 0,737 & 0,3 & Valid \\
\hline & $\mathrm{M}_{.7}$ & 0,756 & 0,3 & Valid \\
\hline & M.8 & 0,621 & 0,3 & Valid \\
\hline & M.9 & 0,579 & 0,3 & Valid \\
\hline & $\mathbf{M}_{1.0}$ & 0,723 & 0,3 & Valid \\
\hline & $\mathrm{M}_{.11}$ & 0,711 & 0,3 & Valid \\
\hline
\end{tabular}

Bersambung... 


\begin{tabular}{lllll} 
Lanjutan Tabel 5. & Indikator & $\begin{array}{l}\text { Koefisien } \\
\text { Korelasi }\end{array}$ & $\begin{array}{l}\text { Koefisien } \\
\text { Batas }\end{array}$ & Keterangan \\
\hline & $\mathrm{M} .12$ & 0,764 & 0,3 & Valid \\
Organizational & $\mathrm{Y} .1$ & 0,708 & 0,3 & Valid \\
Citizenship Behavior $(\mathrm{Y})$ & $\mathrm{Y} .2$ & 0,650 & 0,3 & Valid \\
& $\mathrm{Y} .3$ & 0,523 & 0,3 & Valid \\
& $\mathrm{Y} .4$ & 0,600 & 0,3 & Valid \\
& $\mathrm{Y} .5$ & 0,718 & 0,3 & Valid \\
& $\mathrm{Y} .6$ & 0,685 & 0,3 & Valid \\
& $\mathrm{Y} .7$ & 0,508 & 0,3 & Valid \\
& $\mathrm{Y} .8$ & 0,608 & 0,3 & Valid \\
& $\mathrm{Y} .9$ & 0,702 & 0,3 & Valid \\
& $\mathrm{Y} .10$ & 0,628 & 0,3 & Valid \\
& $\mathrm{Y} .11$ & 0,698 & 0,3 & Valid \\
& $\mathrm{Y} .12$ & 0,853 & 0,3 & Valid \\
& $\mathrm{Y} .13$ & 0,684 & 0,3 & Valid \\
& $\mathrm{Y} .14$ & 0,810 & 0,3 & Valid \\
& $\mathrm{Y} .15$ & 0,666 & 0,3 & Valid \\
\hline
\end{tabular}

Sumber: Data primer diolah, 2019

Hasil uji reliabilitas yang disajikan dalam Tabel 6. menunjukkan bahwa seluruh instrumen penelitian memiliki koefisien Cronbach's Alpha lebih dari 0,60. Jadi dapat dinyatakan bahwa seluruh variabel telah memenuhi syarat reliabilitas atau kehandalan sehingga dapat digunakan untuk melakukan penelitian.

Tabel 6.

Rekapitulasi Hasil Uji Reliabilitas Instrumen Penelitian

\begin{tabular}{llll}
\hline No. & Variabel & $\begin{array}{l}\text { Cronbadh's } \\
\text { Alpha }\end{array}$ & Keterangan \\
\hline 1 & Gaya Kepemimpinan Transformasional (X) & 0,903 & Reliabel \\
2 & Kepuasan Kerja (M) & 0,914 & Reliabel \\
3 & Organizational Citizenship Behavior $(\mathrm{Y})$ & 0,908 & Reliabel \\
\hline
\end{tabular}
Sumber: Data diolah, 2019

Pengumpulan data melalui kuesioner terdiri atas pernyataan responden berdasarkan masing-masing variabel, yaitu: gaya kepemimpinan transformasional, kepuasan kerja dan organizational citizenship behavior. Penilaian responden mengenai variabel-variabel dalam penelitian perlu dilakukan penentuan distribusi frekuensi berdasarkan nilai intervalnya, adapun untuk menentukan nilai interval yang dimaksud adalah sebagai berikut. Skor pada penelitian ini memiliki nilai tertinggi maksimal 5 dan terendah minimal 1, sehingga dapat disusun kriteria pengukuran pada Tabel 7.

Variabel gaya kepemimpinan transformasional dalam penelitian ini merupakan variabel bebas yang diukur dengan menggunakan 19 pernyataan yang berhubungan dengan gaya kepemimpinan transformasional dari responden. Secara 
rinci hasil penelitian mengenai jawaban responden terhadap variabel gaya kepemimpinan transformasional dapat dilihat pada Tabel 8.

Tabel 7.

Kriteria Pengukuran Deskripsi Variabel Penelitian

\begin{tabular}{lllll}
\hline No. & $\begin{array}{l}\text { Skala } \\
\text { Pengukuran }\end{array}$ & $\begin{array}{l}\text { Gaya } \\
\text { Transformasional }\end{array}$ & $\begin{array}{l}\text { Kepemimpinan } \\
\text { Kepuasan } \\
\text { Kerja }\end{array}$ & $\begin{array}{l}\text { Organizational } \\
\text { Citizenship Behavior }\end{array}$ \\
\hline 1 & $1,00-1,80$ & $\begin{array}{l}\text { Sangat } \\
\text { Tidak Baik }\end{array}$ & $\begin{array}{l}\text { Sangat Tidak } \\
\text { Puas }\end{array}$ & Sangat Tidak Baik \\
2 & $1,81-2,60$ & Tidak Baik & Tidak Puas & Tidak Baik \\
3 & $2,61-3,40$ & Cukup & Cukup & Cukup \\
4 & $3,41-4,20$ & Baik & Puas & Baik \\
5 & $4,21-5,00$ & Sangat Baik & Sangat Puas & Sangat Baik \\
\hline
\end{tabular}

Sumber: Ghozali \& Chairi (2016)

Tabel 8.

Deskripsi Jawaban Responden Terhadap

Gaya Kepemimpinan Transformasional

\begin{tabular}{|c|c|c|c|c|c|c|c|c|}
\hline \multirow[t]{2}{*}{ No } & \multirow[t]{2}{*}{ Pernyataan } & \multicolumn{2}{|c|}{$\begin{array}{l}\text { Frekuensi } \\
\text { Responden }\end{array}$} & \multicolumn{3}{|c|}{ Jawaban } & \multirow{2}{*}{$\begin{array}{l}\text { Rata- } \\
\text { Rata }\end{array}$} & \multirow[t]{2}{*}{ Kriteria } \\
\hline & & STS & TS & $\mathbf{N}$ & $\mathbf{S}$ & SS & & \\
\hline 1 & $\begin{array}{l}\text { Pemimpin memberikan motivasi } \\
\text { kepada saya untuk bekerja lebih } \\
\text { baik. }\end{array}$ & 0 & 1 & 17 & 18 & 9 & 3,78 & Baik \\
\hline 2 & $\begin{array}{l}\text { Pemimpin menumbuhkan rasa } \\
\text { percaya diri saya dalam } \\
\text { melakukan pekerjaan. }\end{array}$ & 0 & 0 & 18 & 20 & 7 & 3,76 & Baik \\
\hline 3 & $\begin{array}{l}\text { Pemimpin memberikan } \\
\text { keyakinan kepada saya bahwa } \\
\text { tujuan perusaan akan tercapai. }\end{array}$ & 0 & 0 & 22 & 16 & 7 & 3,67 & Baik \\
\hline 4 & $\begin{array}{l}\text { Pemimpin membangkitan } \\
\text { antusiasme saya untuk } \\
\text { melakukan pekerjaan. }\end{array}$ & 0 & 0 & 12 & 23 & 10 & 3,96 & Baik \\
\hline 5 & $\begin{array}{l}\text { Pemimpin melakukan } \\
\text { komunikasi tentang pekerjaan } \\
\text { dengan jelas. }\end{array}$ & 0 & 0 & 17 & 15 & 13 & 3,91 & Baik \\
\hline 6 & $\begin{array}{l}\text { Pemimpin merupakan Role } \\
\text { Model (panutan) saya dalam } \\
\text { perusahaan. }\end{array}$ & 0 & 1 & 21 & 17 & 6 & 3,62 & Baik \\
\hline 7 & $\begin{array}{l}\text { Pemimpin memberikan petunjuk } \\
\text { kepada saya bagaimana } \\
\text { menyelesaikan suatu pekerjaan. }\end{array}$ & 0 & 0 & 20 & 15 & 10 & 3,78 & Baik \\
\hline 8 & $\begin{array}{l}\text { Pemimpin menanamkan rasa } \\
\text { bangga saya selama bergabung } \\
\text { bersamanya. }\end{array}$ & 0 & 0 & 16 & 21 & 8 & 3,82 & Baik \\
\hline 9 & $\begin{array}{l}\text { Pemimpin saya mendapatkan } \\
\text { rasa hormat hormat dari para } \\
\text { pegawai. }\end{array}$ & 0 & 0 & 18 & 22 & 5 & 3,71 & Baik \\
\hline 10 & $\begin{array}{l}\text { Pemimpin mendorong saya } \\
\text { untuk menggunakan kreativitas } \\
\text { dalam menyelesaikan pekerjaan. }\end{array}$ & 0 & 0 & 16 & 17 & 12 & 3,91 & Baik \\
\hline
\end{tabular}


Lanjutan Tabel 8.

\begin{tabular}{|c|c|c|c|c|c|c|c|c|}
\hline \multirow[t]{2}{*}{ No } & \multirow[t]{2}{*}{ Pernyataan } & \multicolumn{2}{|c|}{$\begin{array}{l}\text { Frekuensi } \\
\text { Responden }\end{array}$} & \multicolumn{3}{|c|}{ Jawaban } & \multirow{2}{*}{$\begin{array}{l}\text { Rata- } \\
\text { Rata }\end{array}$} & \multirow[t]{2}{*}{ Kriteria } \\
\hline & & STS & TS & $\mathbf{N}$ & $\mathbf{S}$ & SS & & \\
\hline 11 & $\begin{array}{l}\text { Pemimpin mendorong saya } \\
\text { untuk selalu inovatif dalam } \\
\text { menyelesaikan pekerjaan. }\end{array}$ & 0 & 1 & 19 & 13 & 12 & 3,80 & Baik \\
\hline 12 & $\begin{array}{l}\text { Pemimpin saya bersemangat } \\
\text { untuk mendengarkan } \\
\text { ide/gagasan saya. }\end{array}$ & 0 & 0 & 20 & 16 & 9 & 3,76 & Baik \\
\hline 13 & $\begin{array}{l}\text { Pemimpin mendorong saya } \\
\text { untuk menyelesaikan masalah } \\
\text { pekerjaan secara rasional/logis. }\end{array}$ & 0 & 0 & 11 & 24 & 10 & 3,98 & Baik \\
\hline 14 & $\begin{array}{l}\text { Pemimpin menyelesaikan } \\
\text { masalah dari berbagai sudut } \\
\text { pandang. }\end{array}$ & 0 & 1 & 7 & 28 & 9 & 4,00 & Baik \\
\hline 15 & $\begin{array}{l}\text { Pemimpin berupaya } \\
\text { meningkatkan pengembangan } \\
\text { diri saya. }\end{array}$ & 0 & 0 & 12 & 19 & 14 & 4,04 & Baik \\
\hline 16 & $\begin{array}{l}\text { Pemimpin memperlakukan saya } \\
\text { sebagai individu pribadi, bukan } \\
\text { hanya sebagai anggota dari suatu } \\
\text { keompok kerja. }\end{array}$ & 0 & 0 & 17 & 20 & 8 & 3,80 & Baik \\
\hline 17 & $\begin{array}{l}\text { Pemimpin bersedia } \\
\text { mendengarkan kesulitan dan } \\
\text { keluhan yang saya alami. }\end{array}$ & 0 & 0 & 25 & 13 & 7 & 3,60 & Baik \\
\hline 18 & $\begin{array}{l}\text { Pemimpin memberikan nasihat } \\
\text { yang sangat penting bagi } \\
\text { pengembangan diri saya. }\end{array}$ & 0 & 0 & 16 & 15 & 14 & 3,96 & Baik \\
\hline 19 & $\begin{array}{l}\text { Pemimpin saya memperlakukan } \\
\text { pegawai sebagai individu yang } \\
\text { masing-masing memiliki } \\
\text { kebutuhan, kemampuan, dan } \\
\text { aspirasi yang berbeda. }\end{array}$ & 0 & 0 & 17 & 13 & 15 & 3,96 & Baik \\
\hline \multicolumn{7}{|c|}{ Rata-rata keseluruhan variabel gaya kepemimpinan transformasional } & 3,83 & Baik \\
\hline
\end{tabular}

Sumber : Data Primer diolah, 2019

Tabel 8. menunjukkan gaya kepemimpinan transformasional secara keseluruhan baik hal ini dapat dilihat dari keseluruhan rata-rata nilai gaya kepemimpinan transformasional yaitu 3,83. Nilai rata-rata tertinggi pada pernyataan "Pemimpin berupaya meningkatkan pengembangan diri saya". Hal ini menunjukan pemimpin berupaya meningkatkan pengembangan diri karyawannya. Nilai rata-rata terendah terdapat pada pernyataan "Pemimpin bersedia mendengarkan kesulitan dan keluhan yang saya alami". Hal ini menunjukan bahwa atasan saya kurang maksimal memberi masukan dan dorongan terkait dengan keluhan - keluhan yang dialami oleh pegawai.

Variabel Kepuasan Kerja dalam penelitian ini merupakan variabel mediasi yang diukur dengan menggunakan 12 pernyataan yang berhubungan dengan kepuasan kerja. Secara rinci hasil penelitian mengenai persepsi responden terhadap variabel Kepuasan Kerja disajikan pada Tabel 9. 
Tabel 9.

Deskripsi Jawaban Responden Terhadap Variabel Kepuasan Kerja

\begin{tabular}{|c|c|c|c|c|c|c|c|c|}
\hline \multirow[t]{2}{*}{ No } & \multirow[t]{2}{*}{ Pernyataan } & \multicolumn{3}{|c|}{$\begin{array}{l}\text { Frekuensi } \\
\text { Responden }\end{array}$} & \multicolumn{2}{|c|}{ Jawaban } & \multirow{2}{*}{$\begin{array}{l}\text { Rata- } \\
\text { Rata }\end{array}$} & \multirow[t]{2}{*}{ Kriteria } \\
\hline & & STS & TS & $\mathbf{N}$ & $\mathbf{S}$ & SS & & \\
\hline 1 & $\begin{array}{l}\text { Saya percaya gaji yang saya } \\
\text { terima setara dengan } \\
\text { jumlah pekerjaan yang saya } \\
\text { lakukan }\end{array}$ & 0 & 0 & 14 & 18 & 13 & 3,98 & Puas \\
\hline 2 & $\begin{array}{l}\text { Saya bersedia untuk bekerja } \\
\text { lebih keras karena } \\
\text { gaji saya }\end{array}$ & 0 & 0 & 16 & 16 & 13 & 3,93 & Puas \\
\hline 3 & $\begin{array}{l}\text { Saya rasa pekerjaan saya } \\
\text { menarik dari waktu ke waktu }\end{array}$ & 0 & 0 & 18 & 15 & 12 & 3,87 & Puas \\
\hline 4 & $\begin{array}{l}\text { Saya memiliki kesempatan } \\
\text { untuk mengerjakan pekerjaan } \\
\text { dengan "cara" saya sendiri }\end{array}$ & 0 & 0 & 18 & 14 & 13 & 3,89 & Puas \\
\hline 5 & $\begin{array}{l}\text { Saya memadai untuk } \\
\text { melakukan pekerjaan ini }\end{array}$ & 0 & 0 & 15 & 20 & 10 & 3,89 & Puas \\
\hline 6 & $\begin{array}{l}\text { Saya memiliki kesempatan } \\
\text { untuk menjadi seseorang } \\
\text { yang diperhitungkan dalam } \\
\text { organisasi }\end{array}$ & 0 & 0 & 16 & 17 & 12 & 3,91 & Puas \\
\hline 7 & $\begin{array}{l}\text { Pekerjaan saya memberi } \\
\text { peluang kepada saya untuk } \\
\text { belajar keterampilan baru } \\
\text { tentang peningkatan karir }\end{array}$ & 0 & 0 & 16 & 21 & 8 & 3,82 & Puas \\
\hline 8 & $\begin{array}{l}\text { Adanya kebebasan untuk } \\
\text { menggunakan penilaian saya } \\
\text { sendiri }\end{array}$ & 0 & 0 & 12 & 19 & 14 & 4,04 & Puas \\
\hline 9 & $\begin{array}{l}\text { Saya memiliki kesempatan } \\
\text { untuk melakukan banyak hal } \\
\text { bagi karyawan lain }\end{array}$ & 0 & 0 & 15 & 20 & 10 & 3,89 & Puas \\
\hline 10 & $\begin{array}{l}\text { Cara teman kerja saya } \\
\text { berhubungan dengan satu } \\
\text { sama lain sangat } \\
\text { menyenangkan }\end{array}$ & 0 & 0 & 19 & 18 & 8 & 3,76 & Puas \\
\hline 11 & $\begin{array}{l}\text { Cara atasan saya menangani } \\
\text { para pekerjanya patut di } \\
\text { teladani }\end{array}$ & 0 & 0 & 14 & 17 & 14 & 4,00 & Puas \\
\hline 12 & $\begin{array}{l}\text { Atasan saya memiliki } \\
\text { kemampuan membuat sebuah } \\
\text { keputusan dengan cepat dan } \\
\text { tepat }\end{array}$ & 0 & 0 & 21 & 9 & 15 & 3,87 & Puas \\
\hline Rata- & ata keseluruhan variabel Kep & 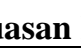 & & & & & 3,90 & Puas \\
\hline
\end{tabular}

Sumber : Data Primer diolah, 2019

Tabel 9. menunjukkan secara keseluruhan rata-rata jawaban responden terhadap variabel kepuasan kerja memiliki nilai sebesar 3,90. Hasil penyebaran kuisioner menunjukkan bahwa pernyataan "Adanya kebebasan untuk menggunakan penilaian saya sendiri" memiliki nilai rata-rata paling tinggi, hal ini 
berarti ada kebebasan untuk menggunakan penilaian saya sendiri. Nilai rata-rata terendah terdapat pada pernyataan "Cara teman kerja saya berhubungan dengan satu sama lain sangat menyenangkan". Hal ini menunjukan bahwa cara teman kerja karyawan berhubungan dengan satu sama lain kurang menyenangkan.

Organizational citizenship behavior dalam penelitian ini merupakan variabel terikat yang diukur dengan menggunakan 15 pernyataan yang berhubungan dengan organizational citizenship behavior. Secara rinci hasil penelitian mengenai persepsi responden terhadap variabel organizational citizenship behavior disajikan pada Tabel 10.

Tabel 10.

Deskripsi Jawaban Responden Terhadap Variabel Organizational Citizenship Behavior

\begin{tabular}{|c|c|c|c|c|c|c|c|c|}
\hline \multirow{2}{*}{ No } & \multirow{2}{*}{ Pernyataan } & \multicolumn{5}{|c|}{ Frekuensi Jawaban Responden } & \multirow{2}{*}{$\begin{array}{l}\text { Rata- } \\
\text { Rata }\end{array}$} & \multirow{2}{*}{ Kriteria } \\
\hline & & STS & TS & $\mathbf{N}$ & $\mathbf{S}$ & SS & & \\
\hline 1 & $\begin{array}{l}\text { Saya pernah dengan senang } \\
\text { hati membantu teman sekerja } \\
\text { yang membutuhkan bantuan } \\
\text { tanpa mengaharapkan } \\
\text { imbalan }\end{array}$ & 0 & 0 & 13 & 16 & 16 & 4,07 & Baik \\
\hline 2 & $\begin{array}{l}\text { Saya pernah menggantikan } \\
\text { rekan kerja yang tidak } \\
\text { masuk/istirahat }\end{array}$ & 0 & 0 & 19 & 12 & 14 & 3,89 & Baik \\
\hline 3 & $\begin{array}{l}\text { Saya bersedia untuk bekerja } \\
\text { lembur untuk membantu } \\
\text { rekan kerja saya } \\
\text { menyelesaikan pekerjaannya } \\
\text { tanpa dikenakan gaji lembur }\end{array}$ & 0 & 0 & 14 & 16 & 15 & 4,02 & Baik \\
\hline 4 & $\begin{array}{l}\text { Saya merasa puas dalam hati } \\
\text { bila pekerjaan saya selesai } \\
\text { tepat pada waktunya }\end{array}$ & 0 & 0 & 15 & 14 & 16 & 4,02 & Baik \\
\hline 5 & $\begin{array}{l}\text { Setiap tugas yang diberikan } \\
\text { akan saya selesaikan dengan } \\
\text { penuh tanggung jawab }\end{array}$ & 0 & 0 & 17 & 12 & 16 & 3,98 & Baik \\
\hline 6 & $\begin{array}{l}\text { Saya berani mengambil resiko } \\
\text { apapun untuk bertanggung } \\
\text { jawab dan melaksanakan hasil } \\
\text { keputusan rapat bersama }\end{array}$ & 0 & 0 & 11 & 19 & 15 & 4,09 & Baik \\
\hline 7 & $\begin{array}{l}\text { Saya selalu terlibat dalam } \\
\text { fungsi-fungsi perusahaan }\end{array}$ & 0 & 0 & 6 & 25 & 14 & 4,18 & Baik \\
\hline 8 & $\begin{array}{l}\text { saya pernah mengajak rekan } \\
\text { kerja saya untuk makan siang } \\
\text { bersama dan sharing } \\
\text { mengenai kendala atau } \\
\text { masalah yang dihadapi dalam } \\
\text { menyelesaikan tugasnya }\end{array}$ & 0 & 0 & 16 & 17 & 12 & 3,91 & Baik \\
\hline 9 & $\begin{array}{l}\text { Saya pernah mengingatkan } \\
\text { teman saya agar tidak lupa } \\
\text { menyelesaikan tugasnya }\end{array}$ & 0 & 0 & 9 & 19 & 17 & 4,18 & Baik \\
\hline
\end{tabular}




\begin{tabular}{|c|c|c|c|c|c|c|c|c|}
\hline \multirow{2}{*}{ No } & \multirow{2}{*}{ Pernyataan } & \multicolumn{5}{|c|}{ Frekuensi Jawaban Responden } & \multirow{2}{*}{$\begin{array}{l}\text { Rata- } \\
\text { Rata }\end{array}$} & \multirow{2}{*}{ Kriteria } \\
\hline & & STS & TS & $\mathbf{N}$ & $\mathbf{S}$ & SS & & \\
\hline 10 & $\begin{array}{l}\text { Saya mudah beradaptasi } \\
\text { dengan perubahan yang } \\
\text { terjadi dalam perusahaan }\end{array}$ & 0 & 0 & 12 & 17 & 16 & 4,09 & Baik \\
\hline 11 & $\begin{array}{l}\text { Saya tidak pernah mengeluh } \\
\text { tentang tugas dan kebijakan } \\
\text { perusahaan }\end{array}$ & 0 & 0 & 9 & 18 & 18 & 4,20 & Baik \\
\hline 12 & $\begin{array}{l}\text { Jika perusahaan } \\
\text { memberlakukan kebijakan } \\
\text { baru dan tidak sesuai dengan } \\
\text { pendapat saya. Saya akan } \\
\text { menyesuaikan diri dan } \\
\text { melaksanakan kebijakan } \\
\text { tersebut }\end{array}$ & 0 & 0 & 17 & 13 & 15 & 3,96 & Baik \\
\hline 13 & $\begin{array}{l}\text { Saya rutin mengikuti } \\
\text { kegiatan-kegiatan yang } \\
\text { diadakan perusahaan tempat } \\
\text { Saya bekerja }\end{array}$ & 0 & 0 & 11 & 19 & 15 & 4,09 & Baik \\
\hline 14 & $\begin{array}{l}\text { Saya tertarik untuk mencari } \\
\text { informasi-informasi penting } \\
\text { yang dapat bermanfaat bagi } \\
\text { perusahaan }\end{array}$ & 0 & 0 & 15 & 17 & 13 & 3,96 & Baik \\
\hline 15 & $\begin{array}{l}\text { Saya selalu } \\
\text { mempertimbangkan hal-hal } \\
\text { terbaik untuk kemajuan } \\
\text { perusahaan kedepannya }\end{array}$ & 0 & 0 & 15 & 18 & 12 & 3,93 & Baik \\
\hline Rat & rata keseluruhan variabel $O$ & Inizati & al C & on & & ior & 4,04 & Baik \\
\hline
\end{tabular}
Sumber : Data Primer diolah, 2019

Tabel 10. menunjukkan secara keseluruhan rata-rata jawaban responden terhadap variabel organizational citizenship behavior memiliki nilai sebesar 4,04. Hasil penyebaran kuisioner menunjukkan bahwa organizational citizenship behavior perusahaan baik. Nilai rata-rata tertinggi terdapat pada pernyataan "Saya tidak pernah mengeluh tentang tugas dan kebijakan perusahaan". Hal ini menunjukan bahwa karyawan tidak pernah mengeluh tentang tugas dan kebijakan perusahaan. Nilai rata-rata terendah terdapat pada pernyataan "Saya pernah menggantikan rekan kerja yang tidak masuk/istirahat. Hal ini menunjukkan bahwa beberapa karyawan jarang menggantikan rekan kerja yang tidak masuk/istirahat.

Suatu model secara teoritis menghasilkan nilai parameter penduga yang tepat bila memenuhi persyaratan asumsi klasik regresi, yaitu meliputi uji normalitas, multikolineritas, dan heteroskedastisitas. Uji normalitas bertujuan untuk meyakinkan apakah dalam model regresi terdapat variabel penganggu atau residual terdistribusi normal. Uji normalitas terhadap residual dilakukan dengan menggunakan Kolmogrov-Smirnov Model dengan taraf signifikansi 5 persen, dimana data yang berdistribusi normal jika Asymp Sig(2-tailed) lebih besar dari $0,05(\alpha=5$ persen $)$.

Tabel 11. dapat dilihat bahwa nilai Asymp. Sig. (2-tailed) sebesar 0,200, hasil tersebut mengindikasikan bahwa model persamaan regresi tersebut 
berdistribusi normal karena nilai Asymp. Sig. (2-tailed) lebih besar dari nilai alpha 0,05 .

Tabel 11.

Hasil Uji Normalitas Struktur 1

\begin{tabular}{ll}
\hline & Unstandardized Residual \\
\hline $\mathrm{N}$ & 45 \\
Test Statistics & 0,078 \\
Asymp. Sig. (2-tailed) & 0,200 \\
\hline Sumber: Data diolah, 2019 &
\end{tabular}

Tabel 12.

Hasil Uji Normalitas Struktur 2

\begin{tabular}{ll}
\hline & Unstandardized Residual \\
\hline $\mathrm{N}$ & 45 \\
Test Statistics & 0,062 \\
Asymp. Sig. (2-tailed) & 0,200 \\
\hline Sumber: Data diolah, 2019 &
\end{tabular}

Tabel 12. dapat dilihat bahwa nilai Asymp. Sig. (2-tailed) sebesar 0,200, hasil tersebut mengindikasikan bahwa model persamaan regresi tersebut berdistribusi normal karena nilai Asymp. Sig. (2-tailed) lebih besar dari nilai alpha 0,05 .

Tabel 13.

Hasil Uji Multikoleniaritas

\begin{tabular}{|c|c|c|c|}
\hline Persamaan Struktur & Variabel & Tolerance & VIF \\
\hline $\mathrm{M}=\beta_{1} \mathrm{X}+\mathrm{e}_{1}$ & $\begin{array}{ll}\text { Gaya } & \text { Kepemimpinan } \\
\end{array}$ & 1,000 & $\overline{1,000}$ \\
\hline \multirow[t]{2}{*}{$\mathrm{Y}=\beta_{1} \mathrm{X}+\beta_{2} \mathrm{M}+\mathrm{e}_{2}$} & $\begin{array}{l}\text { Gaya } \quad \text { Kepemimpinan } \\
\text { Transformasional (X) }\end{array}$ & 0,495 & 2,020 \\
\hline & Kepuasan Kerja (M) & 0,495 & 2,020 \\
\hline
\end{tabular}

Sumber: Data diolah, 2019

Tabel 13. dapat dilihat bahwa nilai tolerance dan VIF dari variabel gaya kepemimpinan transformasional dan kepuasan kerja menunjukkan nilai tolerance untuk setiap variabel lebih besar dari 0,1 dan nilai VIF lebih kecil dari 10 yang berarti model persamaan regresi bebas dari multikolinearitas.

Uji heteroskedastisitas bertujuan untuk menguji apakah dalam model regresi ditemukan ketidaksamaan varians dari residual satu pengamatan ke pengamatan lain. Alat uji yang digunakan untuk mengukur gejala heteroskedastisitas adalah Uji Glejser. Model regresi yang baik adalah yang tidak mengandung gejala heteroskedastisitas dinyatakan tidak akan, jika nilai signifkansi lebih besar dari alpha 0,05 .

Tabel 14. dapat dilihat bahwa nilai signifikansi dari variabel gaya kepemimpinan transformasional sebesar 0,492. Nilai tersebut lebih besar dari 0,05 yang berarti tidak terdapat pengaruh antara variabel bebas terhadap absolute 
residual. Dengan demikian, model yang dibuat tidak mengandung gejala heteroskedastisitas.

Tabel 14.

Hasil Uji Heteroskedastisitas Struktur 1

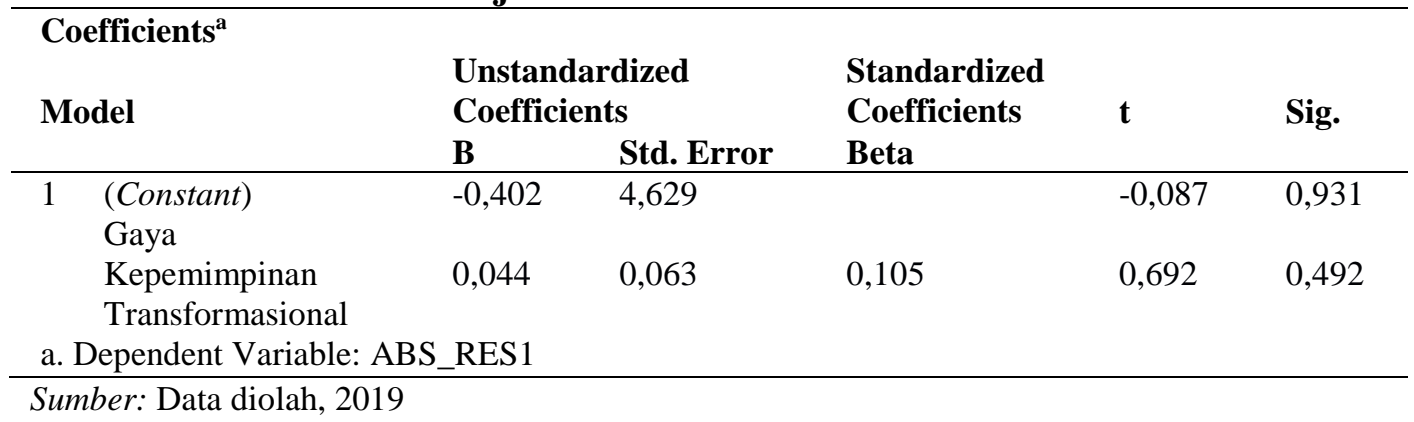

Tabel 15. dapat dilihat bahwa nilai signifikansi dari variabel gaya kepemimpinan transformasional dan kepuasan kerja, masing-masing sebesar 0,245 dan 0,281 . Nilai tersebut lebih besar dari 0,05 yang berarti tidak terdapat pengaruh antara variabel bebas terhadap absolute residual. Dengan demikian, model yang dibuat tidak mengandung gejala heteroskedastisitas.

Tabel 15.

Hasil Uji Heteroskedastisitas Struktur 2

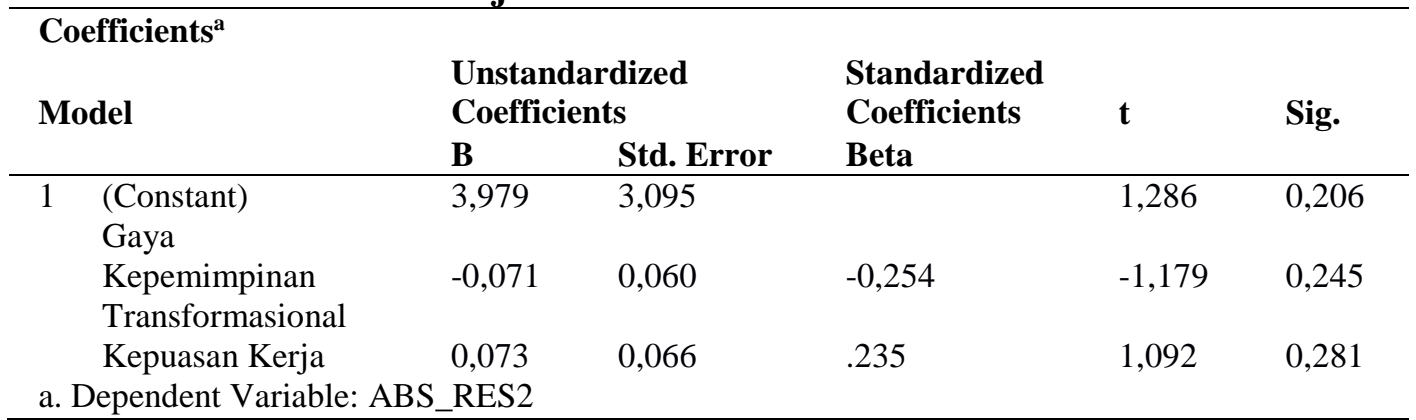

Sumber: Data diolah, 2019

Perhitungan koefisien path dilakukan dengan analisis regresi melalui software SPSS 24.0 for Windows, diperoleh hasil yang ditunjukan pada Tabel 16 Hasil analisis jalur substruktur 1 seperti yang disajikan pada Tabel 16, maka dapat dibuat persamaan struktural sebagai berikut :

$$
\begin{aligned}
& M=\alpha+\beta_{1} X+e_{1} \ldots \ldots \ldots \ldots \ldots \\
& M=-0,030+0,711 X+0,097
\end{aligned}
$$

Nilai koefisien regresi variabel orientasi pasar pada Tabel 16. bernilai positif dengan nilai signifikansi uji t kurang dari 0,05. Hal ini menunjukkan bahwa variabel gaya kepemimpinan transformasional memiliki pengaruh positif yang signifikan terhadap variabel kepuasan kerja. Besarnya pengaruh variabel bebas terhadap variabel terikat yang ditunjukkan oleh nilai determinasi total (R Square) sebesar 0,505 mempunyai arti bahwa sebesar 50,5\% variasi kepuasan kerja 
dipengaruhi oleh variasi gaya kepemimpinan transformasional, sedangkan sisanya sebesar 49,5\% dijelaskan oleh faktor lain yang tidak dimasukkan ke dalam model.

Tabel 16.

Hasil Analisis Jalur 1

\begin{tabular}{|c|c|c|c|c|c|}
\hline \multirow[t]{2}{*}{ Variabel } & \multicolumn{2}{|c|}{$\begin{array}{l}\text { Unstandardized } \\
\text { Coefficients }\end{array}$} & \multirow{2}{*}{$\begin{array}{l}\text { Standardized } \\
\text { Coefficients } \\
\text { Beta }\end{array}$} & \multirow[t]{2}{*}{ t hitung } & \multirow{2}{*}{$\begin{array}{l}\text { Sig. uji } \\
\mathbf{t}\end{array}$} \\
\hline & B & Std. Error & & & \\
\hline (Constant) & $-0,030$ & 7,100 & & $-0,004$ & 0,997 \\
\hline $\begin{array}{l}\text { Gaya Kepemimpinan } \\
\text { Transformasional }(\mathrm{X})\end{array}$ & 0,644 & 0,097 & 0,711 & 6,623 & 0,000 \\
\hline R Square & 0,505 & & & & \\
\hline F Statistik & 43,867 & & & & \\
\hline Signifikansi Uji F & 0,000 & & & & \\
\hline
\end{tabular}

Sumber: Data diolah, 2019

Tabel 17.

Hasil Analisis Jalur 2

\begin{tabular}{|c|c|c|c|c|c|}
\hline \multirow[t]{2}{*}{ Variabel } & \multicolumn{2}{|c|}{$\begin{array}{l}\text { Unstandardized } \\
\text { Coefficients }\end{array}$} & \multirow{2}{*}{$\begin{array}{l}\text { Standardized } \\
\text { Coefficients } \\
\text { Beta }\end{array}$} & \multirow[t]{2}{*}{ t hitung } & \multirow{2}{*}{$\begin{array}{l}\text { Sig. uji } \\
t\end{array}$} \\
\hline & B & Std. Error & & & \\
\hline (Constant) & 10,979 & 5,326 & & 2,062 & 0,045 \\
\hline $\begin{array}{l}\text { Gaya Kepemimpinan } \\
\text { Transformasional }(\mathrm{X})\end{array}$ & 0,513 & 0,104 & 0,607 & 4,953 & 0,000 \\
\hline Kepuasan Kerja (M) & 0,261 & 0,114 & 0,279 & 2,277 & 0,028 \\
\hline $\begin{array}{l}\text { R Square } \\
\text { F Statistik } \\
\text { Signifikansi Uji F }\end{array}$ & $\begin{array}{l}0,688 \\
46,209 \\
0,000\end{array}$ & & & & \\
\hline
\end{tabular}

Sumber: Data diolah, 2019

Hasil analisis jalur substruktur 2 seperti yang disajikan pada Tabel 17, maka dapat dibuat persamaan struktural sebagai berikut:

$$
\begin{aligned}
& \mathrm{Y}=\alpha+\beta_{2} \mathrm{X}+\beta_{3} \mathrm{M}+\mathrm{e}_{2} \ldots \ldots \ldots \ldots \ldots \ldots \ldots \ldots \ldots \ldots \ldots \ldots \ldots \ldots \\
& \mathrm{Y}=10,979+0,607 \mathrm{X}+0,279 \mathrm{M}+0,114
\end{aligned}
$$

Nilai koefisien regresi masing-masing variabel bebas bernilai positif dengan nilai signifikansi uji t kurang dari 0,05 . Hal ini menunjukkan bahwa semua variabel bebas memiliki pengaruh positif yang signifikan terhadap variabel terikat. Besarnya pengaruh variabel bebas terhadap variabel terikat yang ditunjukkan oleh nilai determinasi total ( $\mathrm{R}$ Square) sebesar 0,688 mempunyai arti bahwa sebesar $68,8 \%$ variasi organizational citizenship behavior dipengaruhi oleh variasi gaya kepemimpinan transformasional dan kepuasan kerja, sedangkan sisanya sebesar $31,2 \%$ dijelaskan oleh faktor lain yang tidak dimasukkan ke dalam model.

Berdasarkan model substruktur 1 dan substruktur 2, maka dapat disusun model diagram jalur akhir. Sebelum menyusun model diagram jalur akhir, terlebih dahulu dihitung nilai standar eror sebagai berikut :

$$
\mathrm{Pe}_{1}=\sqrt{1-R_{1}{ }^{2}}=\sqrt{1-0,505}=0,703
$$




$$
\mathrm{Pe}_{2}=\sqrt{1-K_{2}{ }^{2}}=\sqrt{1-0,688}=0,559 .
$$

Berdasarkan perhitungan pengaruh error (Pei), didapatkan hasil pengaruh error $\left(\mathrm{Pe}_{1}\right)$ sebesar 0,703 dan pengaruh error $\left(\mathrm{Pe}_{2}\right)$ sebesar 0,559. Hasil koefisien determinasi total adalah sebagai berikut :

$$
\begin{aligned}
\mathrm{R}^{2}{ }_{\mathrm{m}} & =1-(0,703)^{2}(0,559)^{2} \\
& =1-(0,494)(0,312) \\
& =1-0,154=0,846
\end{aligned}
$$

Nilai determinasi total sebesar 0,846 mempunyai arti bahwa sebesar 84,6\% variasi organizational citizenship behavior dipengaruhi oleh variasi gaya kepemimpinan transformasional dan kepuasan kerja, sedangkan sisanya sebesar $15,4 \%$ djelaskan oleh faktor lain yang tidak dimasukkan ke dalam model.

Kriteria pengujian untuk menjelaskan interpretasi pengaruh antar variabel yakni apabila nilai signifikansi $<0,05$ maka $\mathrm{H}_{0}$ ditolak dan $\mathrm{H}_{1}$ diterima. Sebaliknya, jika nilai signifikansi $>0,05$ maka $\mathrm{H}_{0}$ diterima dan $\mathrm{H}_{1}$ ditolak.

Berdasarkan hasil analisis pengaruh gaya kepemimpinan transformasional terhadap kepuasan kerja diperoleh nilai Signifikansi sebesar 0,000 dengan nilai koefisien beta 0,711 bernilai positif. Nilai Signifikansi $0,000<0,05$ mengindikasikan bahwa $\mathrm{H}_{0}$ ditolak dan $\mathrm{H}_{1}$ diterima. Hasil ini mempunyai arti bahwa gaya kepemimpinan transformasional berpengaruh positif terhadap kepuasan kerja.

Berdasarkan hasil analisis pengaruh gaya kepemimpinan transformasional terhadap organizational citizenship behavior diperoleh nilai Signifikansi sebesar 0,000 dengan nilai koefisien beta 0,607 bernilai positif. Nilai Signifikansi $0,000<$ 0,05 mengindikasikan bahwa $\mathrm{H}_{0}$ ditolak dan $\mathrm{H}_{2}$ diterima. Hasil ini mempunyai arti bahwa gaya kepemimpinan berpengaruh positif terhadap organizational citizenship behaviour.

Berdasarkan hasil analisis pengaruh kepuasan kerja terhadap organizational citizenship behavior diperoleh nilai Signifikansi sebesar 0,028 dengan nilai koefisien beta 0,279 bernilai positif. Nilai Signifikansi $0,028<0,05$ mengindikasikan bahwa $\mathrm{H}_{0}$ ditolak dan $\mathrm{H}_{3}$ diterima. Hasil ini mempunyai arti bahwa kepuasan kerja berpengaruh positif terhadap organizational citizenship behaviour.

Uji Sobel digunakan dengan menguji kekuatan pengaruh tidak langsung variabel gaya kepemimpinan transformasional (X) terhadap variabel Organizational Citizenship Behavior (Y) melalui variabel kepuasan kerja (M). Oleh karena $Z$ hitung sebesar 5,869 > 1,96. Artinya kepuasan kerja menjadi mediasi pada hubungan gaya kepemimpinan transformasional terhadap organizational citizenship behaviour. Karena nilai VAF (22,5 persen) lebih dari 20 persen, maka dapat dijelaskan bahwa ada efek mediasi atau dengan kata lain kepuasan kerja sebagai pemediasi parsial (partial mediation).

Hasil analisis pengaruh gaya kepemimpinan transformasional terhadap kepuasan kerja diperoleh nilai signifikansi sebesar 0,000 dengan nilai koefisien beta 0,711 bernilai positif. Nilai Signifikansi $0,000<0,05$ mengindikasikan bahwa $\mathrm{H}_{0}$ ditolak dan $\mathrm{H}_{1}$ diterima. Hasil ini mempunyai arti bahwa gaya kepemimpinan transformasional berpengaruh positif terhadap kepuasan kerja. 
Dengan kepuasan kerja yang tinggi karyawan akan memiliki kualitas kinerja yang tinggi. Hal ini sesuai dengan penelitian yang dilakukan oleh Astrayana \& Sriathi (2014), Rahman et al., (2014), dan Dewi \& Subudi (2015). Penelitian ini menunjukkan bahwa kepemimpinan transformasional memiliki pengaruh positif dan signifikan terhadap kepuasan kerja karyawan. Hasil penelitian yang dilakukan oleh Andreani \& Petrik (2016) terhadap 68 karyawan juga menunjukkan adanya hubungan positif dan signifikan antara kepemimpinan transformasional dengan kepuasan kerja karyawan. Semakin tinggi nilai Gaya Kepemimpinan Transformasional yang ditunjukkan pemimpin maka kepuasan kerja dari pegawai akan meningkat.

Hasil analisis data menunjukan bahwa analisis pengaruh gaya kepemimpinan transformasional terhadap organizational citizenship behavior diperoleh nilai signifikansi sebesar 0,000 dengan nilai koefisien beta 0,607 bernilai positif. Nilai Signifikansi $0,000<0,05$ mengindikasikan bahwa Ho ditolak dan $\mathrm{H} 2$ diterima. Hasil ini mengindikasikan bahwa gaya kepemimpinan berpengaruh positif terhadap organizational citizenship behaviour.

Hasil analisis data diperoleh bahwa pengaruh kepuasan kerja terhadap organizational citizenship behavior diperoleh nilai signifikansi sebesar 0,028 dengan nilai koefisien beta 0,279 bernilai positif. Nilai Signifikansi 0,028 $<0,05$ mengindikasikan bahwa Ho ditolak dan H3 diterima. Hasil ini mempunyai arti bahwa kepuasan kerja berpengaruh positif terhadap organizational citizenship behaviour.

Kepuasan kerja adalah penilaian dari seberapa jauh pekerjaan yang dijalankan secara keseluruhan memuaskan kebutuhannya. Kepuasan kerja juga adalah sikap umum yang merupakan hasil dari beberapa sikap khusus terhadap faktor-faktor pekerjaan, penyesuaian diri dan hubungan sosial individu di luar kerja. Penelitian lain juga menyatakan kepuasan kerja berpengaruh positif dan signifikan terhadap perilaku Organizational Citizenship Behavior Mushtaq \& Umar (2015), Rahman et al. (2014), Dewanggana et al. (2016), Subawa \& Suwandana (2017). Pemaparan tersebut sesuai dengan penelitian terdahulu yang dilakukan oleh Dewi \& Suwandana (2016) terhadap 41 karyawan hotel juga menunjukkan bahwa kepuasan kerja karyawan berpengaruh secara positif dan signifikan terhadap OCB.

Kepuasan kerja berpengaruh positif dan signifikan sebagai mediasi antara gaya kepemimpinan transformasional terhadap Organizational Citizenship Behavior. Gaya kepemimpinan transformasional dapat memberikan dorongan serta motivasi sehingga kualitas kepuasan kerja meningkat. Kualitas kepuasan kerja yang tinggi akan memberikan standar kinerja yang tinggi pada karyawan. Dengan demikian dapat dinyatakan bahwa Kepuasan kerja berpengaruh positif dan signifikan sebagai mediasi antara gaya kepemimpinan transformasional terhadap Organizational Citizenship Behavior. Hubungan antara kepemimpinan transformasional dan organizational citizenship behavior melalui kepuasan kerja dibuktikan dengan penelitian yang dilakukan oleh (Susastra \& Subudi., 2016). Penelitian tersebut menunjukkan bahwa kepuasan kerja dapat berfungsi sebagai variabel intervening antara kepemimpinan transformasional dengan Organizational Citizenship Behavior. Hal ini juga didukung dari penelitian 
Kartono et al. (2015), Purwaningsih \& Liana (2015), Arifiani et al. (2016) bahwa kepuasan kerja memediasi pengaruh gaya kepemimpinan transformasional terhadap OCB.

\section{SIMPULAN}

Simpulan dari hasil penelitian ini, berdasarkan hasil analisis dan pembahasan yang telah dipaparkan adalah sebagai berikut. Gaya kepemimpinan transformasional berpengaruh positif terhadap kepuasan kerja di Kantor Desa Ubung Kaja. Hal ini menunjukan bahwa jika gaya kepemimpinan transformasional semakin meningkat maka akan meningkatkan pula kepuasan kerja di Kantor Desa Ubung Kaja.

Gaya kepemimpinan transformasional berpengaruh positif terhadap organizational citizenship behavior di Kantor Desa Ubung Kaja. Hal ini menunjukan bahwa jika gaya kepemimpinan transformasional semakin meningkat maka akan meningkatkan pula organizational citizenship behavior di Kantor Desa Ubung Kaja. Kepuasan kerja berpengaruh positif dan signifikan terhadap organizational citizenship behavior di Kantor Desa Ubung Kaja. Hal ini menunjukan bahwa jika kepuasan kerja semakin meningkat maka akan meningkatkan pula organizational citizenship behavior di Kantor Desa Ubung Kaja. Kepuasan kerja secara positif memediasi pengaruh gaya kepemimpinan transformasional terhadap organizational citizenship behaviour di Kantor Desa Ubung Kaja. Hal ini menunjukan bahwa gaya kepemimpinan transformasional memberikan dampak yang signifikan terhadap organizational citizenship behavior jika di mediasi oleh kepuasan kerja, yang berarti bahwa organizational citizenship behavior sangat tergantung pada tingkat kepuasan kerja tersebut dan juga tingkat gaya kepemimpinan transformasional di Kantor Desa Ubung Kaja. Saran yang diberikan dalam penelitian ini, berdasarkan hasil analisis dan pembahasan yang telah dipaparkan adalah sebagai berikut. Untuk menerapkan gaya kepemimpinan transformasional di Kantor Desa Ubung Kaja, Perbekel Desa Ubung Kaja diharapkan agar lebih maksimal lagi untuk memperhatikan bawahannya sehingga keluhan atau kesulitan yang dialami bawahan dapat diketahui oleh seorang pemimpin.

\section{REFERENSI}

Abu, N. M., \& Heilbrunn, S. (2016). Transformational leadership and organizational citizenship behavior in the Arab educational system in Israel: the impact of trust and job satisfaction. Educational Management Administration \& Leadership, 4(3), 380-396.

Ahmed, N., Rasheed, A., \& Jehanzeb, K. (2012). An Exploration of Predictors of Organizational Citizenship Behaviour and Its Significant Link to Employee Engagement,. International Journal of Business, Humanities and Technology, 2(4), 99-106.

Andreani, F., \& Petrik, A. (2016). Employee performance as the impact of transformational leadership and job satisfaction in PT Anugrah Baru 
Denpasar. Jurnal Manajemen Dan Kewirausahaan, 18(1), 25-32.

Arifiani, R. S., Astuti, E. S., \& Ruhana, I. (2016). PENGARUH KEPEMIMPINAN TRANSFORMASIONAL TERHADAP ORGANIZATIONAL CITIZENSHIP BEHAVIOR DAN KEPUASAN KERJA (Studi pada Tenaga Perawat RSUD. Dr. Saiful Anwar Malang). Jurnal Administrasi Bisnis (JAB), 33(1).

Astrayana, I. K. T., \& Sriathi., A. . A. (2014). Pengaruh Pendidikan Dan Pelatihan, Insentif Finansial, Dan Lingkungan Kerja Fisik terhadap Kinerja Pegawai Bappeda Kabupaten Buleleng. E-Jurnal Manajemen Universitas Udayana., 3(10), 3097-3116.

Azeem, S. M. (2010). Job Satisfaction and Organizational Commitment among Employees in the Sultanate of Oman,. Journal of Psychology, 1, 295-299.

Bushra, F., Usman, A., \& Naveed, A. (2011). Effect of Transformational Leadership on Employees Job Satisfaction and Organizational Commitment in Banking Sector of Lahore (Pakistan). International Journal of Business and Social Science, 2(18), 261-267.

Chiang, C. F., \& Hsieh, T. S. (2012). The impacts of perceived organizational support and psychological empowerment on job performance: The mediating effects of organizational citizenship behavior. International Journal of Hospitality Management, 31, 180-190.

Chun, J. U., Cho, K., \& Sosik, J. J. (2016). A multilevel study of group-focused and individual-focused transformational leadership, social exchange relationships, and performance in teams. Journal of Organizational Behavior, 37(3), 374-396.

Cichorzewska, M., \& Rakowska, A. (2017). Organizational citizenship behavior of Polish and Ukrainian civil servants - a comparative study. Technology, Innovation and Industrial Management. Management, Knowledge and Learning International Conference 2017.

Dewanggana, Dhatu, B., Paramita, P. D., \& Haryono, A. T. (2016). Pengaruh Komitmen Organisasi, Kepuasan Kerja, Budaya Organisasi terhadap Organizational Citizenship Behavior (OCB) yang berdampak pada Prestasi Kerja karyawan studi pada PT. PLN APP Semarang. Journal Of Management., 2(2), 1-10.

Dewi, A., \& Suwandana. (2016). Pengaruh kepuasan kerja terhadap organizational citizenship behavior (ocb) dengan komitmen organisasional sebagai variabel mediasi. E-Jurnal Manajemen Unud, 5(9), 5643-5670.

Dewi, C., \& Subudi. (2015). Pengaruh kepemimpinan transfor-masional terhadap 
kepuasan kerja dan turnover intention pada CV Gita Karya Persada Denpasar. E-Jurnal Manaje-Men Unud, 4(12), 4219-4244.

Ghasabeh, M. S., Reaiche, C., \& Soosay, C. (2015). The emerging role of transformational leadership. Journal of Developing Areas, 49(6), 459-467.

Ghozali, I., \& Chairi. (2016). Teori Akuntansi. Semarang: Badan Penerbit Universitas Diponegoro.

Griffin, R. W. (2008). Management. USA.: Mc-Graw Hil.

Guay, R. P., \& Choi, D. (2015). To whom does transformational leadership matter more An examination of neurotic and introverted followers and their organizational citizenship behavior. The Leadership Quarterly, 26(5), 851862.

Iswara, D., \& Sriathi, A. (2016). Pengaruh kepemimpinan trans-formasional, kepuasan kerja dan komitmen organisasi ter-hadap organizational citizenship behavior di PT BPD Bali. E-Jurnal Manajemen Unud, 5(9), 5923-5948.

Jha, S. (2014). Transformational leadership and psychological empowerment: Determinants of organizational citizenship behavior. South Asian Journal of Global Business Research, 3(1), 18-35.

Kartikaningdyah, E., \& Utami, N. K. (2017). Pengaruh kepemimpinan transformasional, kepuasan kerja, keadilan pro-sedural terhadap kinerja karyawan dengan variabel mediasi organizational citizenship behavior. Journal of Business Administration, 1(2), 110-123.

Kartono, M., Mahadianto, Y., \& Mardi. (2015). Mediate Job Satisfaction:Effect of Transformational Leadership on Organizational Citizen Behavior (OCB) (Studies on employees PD. Rural Banks (BPR) in Cirebon). First International Conference on Economics and Banking (ICEB-15).

Khalili, A. (2016). "Linking transformational leadership, creativity, innovation, and innovationsupportive climate." Management Decision, 54(9), 22772293.

Kreitner, R., \& Kinicki, A. (2014). Perilaku Organisasi (Organizational Behavior) (9th ed.). Jakarta: Salemba Empat.

Long, C. S. (2014). The Impact of Transformational Leadership Style on Job Satisfaction. World Applied Sciences Journal.

Mushtaq, K., \& Umar, M. (2015). Association between job satisfaction, motivation and five factors of organizational citizenship behavior. International Journal of Social, Behavioral, Educational, Economic, 
Business and Industrial Engineering, 9(8), 2811-2817.

Nezakati, H., Asgari, O., Karimi, F., \& Kohzadi, V. (2010). Fostering Organizational Citizenship Behavior (OCB) through Human Resource Empowerment (HRE). World Journal of Management, 2(3), 47-64.

Permatasari, L. W., \& Gayatri. (2016). Profitabilitas Sebagai Pemoderasi Pengaruh Good Corporate Governance Pada Nilai Perusahaan. E-Jurnal Akuntansi Universitas Udayana, 14(3), 2307-2335.

Permatasari, D. V., Ghalib, S., \& Irwansyah. (2017). Pengaruh kepemimpinan transforrmasional terhadap organizational citizenship behavior dan komitmen organisasi melalui kepuasan kerja karyawan PT Bank Panin. Jurnal Bisnis Dan Pembangunan, 6(1), 36-42.

Purwaningsih, Y., \& Liana, L. (2015). Pengaruh Kepemimpinan Transformasional Terhadap Organizational Citizenship Behavior Dimesiasi Kepuasan Kerja Dan Komitmen Organisasional Dalam Rangka Menghadapi Persaingan Menyongsong AEC 2015 (Studi Pada Guru Di Smanegeri Di Kecamatan Mranggen Kabupaten . Fakultas Ekonomika Dan Bisnis Universitas Stikubank Semarang.

Rahman, U., Sulaiman, W. S. W., Nasir, R., \& Omar, F. (2014). "The role of job satisfaction as mediator in the relationship between self-efficacy and organizational citizenship behavior among indonesian teachers." International Journal of Business and Social Science, 5(9), 255-261.

Rahmi, B. M. (2014). Pengaruh Kepemimpinan Transformasional Terhadap Organizational Citizenship Behavior Dand Komitmen Organisasi Dengan Mediasi Kepuasan Kerja (Studi pada Guru Tetap SMA Negeri di Kabupaten Lombok Timur). E-Jurnal Manajemen Universitas Udayana, 3(2), 331-350.

Retnaningsih, S. (2007). Analisis Pengaruh Keadilan Kompensasi, Peran Kepemimpinan, dan Kepuasan Kerja Terhadap Komitmen Organisasi dalam Meningkatkan Kinerja Karyawan (Studi Kasus: Pada Sentral Pengolahan Pos Semarang). Tesis Pasca Sarjana Pada Program Magister Manajemen Universitas Diponegoro.

Ristiana, M. (2013). Pengaruh Komitmen Organisasi dan Kepuasan Kerja Terhadap Organizational Citizenship Behavior (OCB) dan Kinerja Karyawan Rumah Sakit Bhayangkara Trijata Denpasar,. Jurnal Ilmu Ekonomi \& Manajemen, 9(1), 56-70.

Robins, S. P., \& Judge, T. A. (2012). Organizational Behavior. US: Prentice Hall.

Subawa, A., \& Suwandana. (2017). Pengaruh kepemimpinan transformasional, kepuasan kerja dan komitmen organisa-sional terhadap organizational 
citizenship behavior. E-Jurnal Manajemen Unud, 6(9), 4772-4799.

Sugiyono. (2017). Metodologi Penelitian Kuantitatif, Kualitatif, dan R\&D. Bandung: CV Alfabeta.

Susastra, W., \& Subudi. (2016). Pengaruh kepemimpinan trans-formasional terhadap kepuasan kerja dan organizational citizeship behavior pada PT Sinar Nusra Press Utama. E-Jurnal Manajemen Unud, 5(6), 3274-3304.

Talachi, R., Mohammad, B., \& Boerhannoeddin, A. B. (2014). An investigation of the role of job satisfaction in employees' organizational citizenship behavior. International Journal Collegium Antropologicum, 38(2), 429-436.

Trmal, S. A., Bustamam, U. S. A., \& Mohamed, Z. A. (2015). The effect of transformational leadership in achieving high performance workforce that exceeds organizational expectation: A study from a global and Islamic perspective. Global Business \& Management Research, 7(2), 88-94.

Zadeh, M. H., Esmaili, M. R., \& Tojari, F. (2015). "Relationship between job satisfaction and organizational justice with organizational citizenship behavior in physical educators." Indian Journal of Fundamental and Applied Life Sciences, 5, 1247-1252. 